\title{
STRATEGY TO INCREASE THE COMPETITIVENESS OF NATIONAL SALT IN INDONESIA
}

\author{
Arif Haendra*), M. Syamsul Maarif ${ }^{*}$, Joko Affandi**), Anggraini Sukmawati ${ }^{* * *}$ \\ ${ }^{*}$ School of Business, IPB University \\ Jl. Pajajaran, Bogor 16151, Indonesia \\ ${ }^{* *}$ PPM School of Management \\ J1. Menteng Raya No.9, Jakarta 10340, Indonesia \\ ${ }^{* * *}$ Department of Management, Faculty of Economics and Management, IPB University \\ Jl. Agatis, IPB Dramaga Campus, Bogor 16680, Indonesia
}

\begin{abstract}
Salt is a strategic commodity and political commodity in Indonesia. However, during the research period, namely in 2015-2019, the national salt production has not been able to meet the demand for salt. This has resulted in national salt consumption still being dependent on imports. This results in a potential dependence on imported salt which can hamper the competitiveness of domestic salt. Local people are increasingly cornered and find it difficult to be competitive. This study aims to analyze the competitiveness of the national salt industry and formulate efforts to increase the competitiveness of the national salt industry. The method used in this research is the Revealed Comparative Advantage (RCA) and Revealed Symmetric Comparative Advantage (RSCA) analysis and the Analytical Hierarchy Process (AHP) method which is one of the analytical tools used to assist managerial decision-makers. The data used in this study are primary data in the form of interviews and questionnaires and secondary data obtained from literature studies. The results showed that the salt commodity was not competitive. This is because Indonesia's salt commodity does not have a comparative advantage.
\end{abstract}

Keywords: AHP, competitiveness, salt industry, RCA, strategy

Abstrak: Garam merupakan komoditas strategi dan komoditas politik di Indonesia. Namun dalam selama periode penelitian yaitu pada tahun 2015-2019, produksi garam nasional belum mampu memenuhi permintaan garam. Hal ini mengakibatkan konsumsi garam nasional masih bergantung terhadap pada impor. Hal ini mengkibatkan adanya potensi ketergantungan terhadap garam impor yang mengakibatkan dapat menghambat daya saing garam domestik. lokal semakin tersudut dan kesulitan untuk dapat berdaya saing. Penelitian ini bertujuan menganalisis daya saing industri garam nasional dan merumuskan upaya peningkatan daya saing garam industri garam nasional. Metode yang digunakan dalam penelitian ini adalah analisis Revealed Comparative Advantage (RCA) dan Revealed Symmetric Comparative Advantage (RSCA) serta metode Analytical Hierarchy Process (AHP) yang merupakan salah satu alat analisis yang digunakan untuk membantu para pengambil keputusan manajerial. Data yang digunakan dalam penelitian ini adalah data primer berupa diperoleh dari wawancara dan kuesioner, serta dan data sekunder berupa diperoleh dari studi literatur. Hasil penelitian menunjukkan bahwa komoditas garam tidak berdaya saing. Hal ini disebabkan komoditas garam Indonesia tidak memiliki keunggulan komparatif.

Kata kunci: $A H P$, daya saing, industri garam, $R C A$, strategi

\footnotetext{
${ }^{1}$ Corresponding author:

Email: ahaendra3314@gmail.com
} 


\section{INTRODUCTION}

Salt is a strategic commodity and political commodity in Indonesia (Salim \& Munadi, 2016). Since 2015, the salt commodity has increasingly experienced a balance between supply and demand. Indonesia is a maritime country with a coastline of $108,000 \mathrm{~km}$ (Biro Komunikasi Kementerian Koordinator Bidang Kemaritiman dan Investasi, 2018). Although not all coastlines can be used as salt production sites locations for the salt industry, Indonesia should have great potential as the largest salt producer in the world with the introduction of not only for consumption salt but also salt for industryial needs (Suhendi et al. 2020).

During the period of 2015-2019, national salt production had a low average value production and tended towith fluctuating production fluctuate, even in In 2016, there was a supply shortage due to national harvest failure that caused a shortage of salt commodities in Indonesia. Even so, the national salt demand is not affected by the low national salt production and continues to have an upward trend every year. To cover fill the gap between national salt production domestic supply and national salt demand, the government decide to do imports (Table 1).

The reasons of the Government of Indonesia government's reason for to importing salt is are to meet the needs of the downstream salt industry which demands specific salt quality, and to maintains price stability by regulating import taps, to increaseing national economic growth with a multiplier effect on the downstream salt industry sector (PT Garam, 2020). However, the magnitude of the production factor is not the only factor that affectings the size amount of Indonesia's salt imports. According to Baihaki (2013), there is a role for the government as a determinant of salt import policy maker that which causes an increase salt stocks in Indonesia to increase and, so the price of salt prices fall dropped sharply. As a result, so that farmers lost money because the salt could not be sold suffer losses.

Salt farmers in Indonesia in producing produce salt using low technology. They also and experience other face challenges in producing high quality of salt such as evaporation of seawater in salt ponds and relatively high humidity which is between $60 \%$ and $-80 \%$, causing salt farmers in Indonesia to have difficulty in producing quality salt (Ardiyanti, 2016). In addition, according to Pushidrosal (2018), Indonesia's has only coastline is $108,000 \mathrm{~km}$ long, but only $250 \mathrm{~km}$ of $108,000 \mathrm{~km}$ coastline which can ideally be used to as salt farming land/ponds (Garampedia, 2020). Therefore, availability of land is the main problem (PT Garam, 2017). The above problems lead to potential distortions in the salt import policy carried out by the government with the import of salt itself (Yonvitner \& Akmal, 2019). However, the available land has not been used optimally, and only 60 percent of the salt agricultural land area is used (Dharmayanti et al. 2013). Various problems that occur in the national salt industry require PT Garam (Persero), state-owned enterprise (BUMN), to have a competitive strategy that is competitive to face to be able to compete imported salt in Indonesia.

The problems faced by the national salt industry are very complex because various problems are interrelated with one another. The main problem regarding the national salt industry is the availability of land (PT GARAM, 2017) the available land has not been used optimally, and only 60 percent of the salt agricultural land area is used (Dharmayanti et al. 2013). Various problems that occur in the national salt industry require PT Garam (Persero) to have a competitive strategy that is competitive to face imported salt in Indonesia.

Table 1. Production, import, and demand consumption for salt in Indonesia in 2015-2019 (tonnes)

\begin{tabular}{cccccc}
\hline Year & $\begin{array}{c}\text { National Salt } \\
\text { Production }\end{array}$ & Import & Total & $\begin{array}{c}\text { National Salt } \\
\text { Consumption }\end{array}$ & Difference \\
\hline 2015 & $2,485,111$ & $1,864,049$ & $4,349,160$ & $3,227,279$ & $1,121,881$ \\
2016 & 168,054 & $2,143,743$ & $2,311,797$ & $3,532,887$ & $-1,221,090$ \\
2017 & $1,111,395$ & $2,552,283$ & $3,663,678$ & $3,862,925$ & $-199,247$ \\
2018 & $2,719,256$ & $2,718,659$ & $5,437,915$ & $3,960,945$ & $1,476,970$ \\
2019 & $2,327,078$ & $2,724,772$ & $5,051,850$ & $4,197,622$ & 854,228 \\
\hline
\end{tabular}


PT Garam is a BUMN engaged in the oldest salt production in Indonesia to which acts as a development agent and consistently maintains the assurance of the availability of national salt and always strives to realize food sovereignty in the salt sector salt selfsufficiency. Currently, PT Garam is the only corporate producer of raw material salt and only with production share accounted of produces $20 \%$ of the total national production. However, PT Garam is has become a reference the benchmark for farmers in determining the price of salt prices by farmers due to reliability both quality and quantity. because, On the other hand, with the same quality of salt, farmers the price of people's salt has a get a lower value than PT Garam. This is because PT Garam is a reliable salt supplier both in terms of quality and quantity. To realize salt self-sufficiency, a competitive strategy is required to increase national salt competitiveness, and to improve farmers income.

PT Garam is a BUMN engaged in the oldest salt production in Indonesia which acts as a development agent and consistently maintains the assurance of the availability of National Salt and always strives to realize food sovereignty in the salt sector.

The analysis of the competitiveness of the national salt industry is the focus of this research. To create salt self-sufficiency in Indonesia, the right strategy is needed to increase salt competitiveness by looking at the production, market, and Indonesian economy to improve the welfare of domestic salt farmers and increase state income.

Marketing development is important for increasing competitiveness According to (Banumathi \& Nadarajan, 2015; Muenshriphu et al. 2010; Wati et al. 2015) in increasing competitiveness carried out in the salt industry, the important thing to improve is in terms of marketing. Moreover, With a salt business development strategiesy, it can also advance salt reform by enriching product variety and strengthening action the development for of counterfeiting and artificial salt (Liu et al. 2016; Mustofa, 2016).

The purpose of this study is to analyse the competitiveness of Indonesia salt and formulate strategies to improve the competitiveness of Indonesian salt. The novelty in this study when compared to previous studies is that the formulation of regulations using the Market based View (MBV) approach is counterproductive to the welfare of salt farmers/farmers. local power. In addition, tThis research study also provides a new understanding to for all stakeholders in Indonesia on about salt business management of in the upstream (increasing productivity and quality), midstream (increased utilization for industry), and downstream (improving market access). Analyzing of competitiveness used Revealed comparative advantage (RCA) and Revealed Symmetric Comparative Advantage (RSCA). The Formulation of regulation novelty in this study when compared to previous studies is that the formulation of regulations using the used Market based View (MBV) approach is counterproductive to the welfare of salt farmers/farmers. and Analytical Hierachy Process (AHP).

Salt from the business aspect and utilization according to national production capabilities associated with a comprehensive salt competitiveness improvement strategy, resulting in a grand strategy in increasing Indonesian salt competitiveness which upstream activities in the form of increased productivity or maximizing production and quality, in the middle in the form of wider utilization efforts for industry and downstream in the form of market strengthening.

In this study, the problem-solving approach taken in analyzing the Analytical Hierarchy Process (AHP) is by Focus Group Discussion (FGD), after which the AHP framework is prepared and then assessed using software that functions to perform pairwise comparison analysis. In addition, to determine the competitiveness of Indonesian salt commodity, RCA \& RSCA analyzes were carried out. The general objective to be achieved in this research is to formulate a strategy to increase the competitiveness of national salt. The specific objectives of this study are to analyze the competitiveness of national salt and to formulate strategies to increase salt competitiveness in Indonesia.

\section{METHODS}

The research was conducted at PT Garam which is a State Owned Enterprises (BUMN), the only company that produces salt continuously in Indonesia. Time Measurement and data collection were carried out from August 2020 - to February 2021. This study was a quantitative descriptive study, and the data collected in this study included primary data and secondary data. Primary data were obtained collected from two 
methods, namely through indirect interviews and direct interviews. Meanwhile, secondary data was obtained collectd from UN COMTRADE.

The indirect interview process was carried out by giving a questionnaire regarding the competitiveness strategy in the national salt industry, while the direct interview process was carried out by Focus Group Discussion (FGD). Respondents for both indirect and direct interviews These two interview methods were conducted with experts consisting of 3 academics, 3 ministries/agencies, and 24 salt industriesy players including farmers who were selected by purposive sampling. The purpose of the interview process is to obtain an analysis of both internal and external factors regarding considerations or inputs in to formulating formulate appropriate recommendations. In the sSecondary data collection process, the data is were tabulated processed withusing Microsoft Excel with data series using 5 years of data taken from 2015 to -2019. The Secondary data taken includes data on exports of salt commodities from each country studied, total exports of all commodities in each country studied, total world exports for salt commodities, and total world exports for all commodities.

Stages of analysis in this study have a function by following followed the objectives of the study. Each analysis tool is designed to be interrelated and complementary to one another. Descriptive statistical analysis is was used to analyze as a quantitative approach to produce primary data from processing for the production of raw materials. Analysis of the questionnaire that data includes knowledge, perceptions and attitudes of respondents about their competences.

AHP research data uses primary data obtained from interviews, questionnaires, andFocus GroupDiscussions (FGD) with experts consisting of 3 academics, 3 ministries/institutions, and 24 salt industry players including farmers, selected by purposive sampling.

To measurement the performance of a country's product competitiveness, used the Balassa Index is used (Prasad, 2004). The calculation of RCA can be seen in formula (1) as follows:

$$
R C A_{J}^{A}=\frac{X_{J}^{A} / X^{A}}{X_{J}^{W} / X_{W}}
$$

Description: $\mathrm{RCA}_{\mathrm{j}}^{\mathrm{A}}$ (Revealed Comparative Advantage for commodity $j$ ); $X_{j}^{A}$ (Export value of country $A$ for commodity j); $X^{A}$ (Total value of country A's exports); $\mathrm{X}_{\mathrm{J}}^{\mathrm{W}}$ (Export value of commodity $\mathrm{j}$ in the world); $\mathrm{X}_{\mathrm{W}}$ (Total world export value ekspor).

RCA value $>1$ indicates that the product or commodity has a high comparative advantage in the market. Conversely, if the RCA value $<1$, this commodity is less able to compete in the global market because it is not efficient. To avoid the occurrence of problems in the RCA value range that is too far, improvements were made by making the RCA index symmetrical with a value interval between -1 to +1 which is known as Revealed Symmetric Comparative Advantage (RSCA) (Prasad, 2004) positive (negative) RSCA show a competitive advantage (disadvantage) for product exports $\mathrm{j}$. The formula for calculating the RSCA can be seen in formula (2) below:

$$
R S C A_{J}^{A}=\frac{\left(R C A_{J}^{A}-1\right)}{\left(R C A_{J}^{A}+1\right)}
$$

Description: $\quad \mathrm{RSCA}_{\mathrm{J}}^{\mathrm{A}} \quad$ (Reveraled Symmetric Comparative Advantage for commodity j).

This study also uses the Analytic Hierarchy Process (AHP) analysis tool. In this study, the Analytic Hierarchy Process (AHP) was used to determine the most effective alternative strategy to increase salt competitiveness in Indonesia. In Figure 1, it can be seen that AHP functions to simplify a complex and unstructured problems, as well as being strategic and dynamic problems through efforts to by organizeing a series of variables in a hierarchy (Figure 1). Schematically, the process of creating and processing AHP data in research can be described in the process as shown below.

\section{RESULTS}

The results of this study have a managerial impact on the main stakeholders of national salt, namely the government and PT Garam. The government must immediately evaluate the regulations governing the salt trade system, remove overlapping authorities and encourage the creation of salt-based industries around salt production centers, in addition to that a revision is needed regarding the determination of salt clustering so that there are changes to the salt import map that makes salt imports consumption is subject to import duty. 
PT Garam must consistently implement off-farm strategies, on-farm strategies and marketing strategies. External pressure in the form of low salt prices has become a momentum for self-improvement, business and management transformation. Businesses must be shifted from an on-farm focus to an off-farm focus. Improving the quality of on farm products must be prioritized as well as increasing the quantity quickly to improve corporate performance with the immediate acquisition of salt fields in Australia.

The potential of national salt can be seen from is reflected in two factorsaspects, the population and industrial needs.demand. These two factors cause the need for increase the demand for consumption salt and industrial salt to increase. According to BPS (2020), the need for consumption salt demand for table salt only increases grows by $1 \%$ per year, while the need the demand for industrial salt increases grows by $5 \%-7 \%$ annually.

In 2020, the total need for salt demand in Indonesia will reach 4,464,670 tons. While on the other hand, it has something to do with related to the supply of table salt. The production of table salt has decreased declined compared with to the previous year. This is caused due to by the La Nina phenomenon and the low uptake absorption rate of people's salt farmers by the manufacturing industry. In addition, besides that in 2020 the salt industry was affected by the Covid-
19 pandemic in 2020, resulting which caused in a gap between the amount of in salt production and demand. of 3,208,174 tons. Therefore, to cover fill the gap, the government implemented there is a salt import policy carried out by the government.

In this study, an analysis of the performance of competitiveness between Indonesia and other countries such as India, Australia, and the Netherlands was conducted analysed. The choice of this country as a comparison of Indonesia's competitiveness performance is based on the fact that India and Australia are the Indonesia's largest salt suppliers countries in Indonesia, and while the Netherlands is the world's largest salt exporter of salt in the world (BPS, 2020).

This study uses Revealed Comparative Advantage (RCA) and Revealed Symmetric Comparative Advantage (RSCA) analysis to determine whether Indonesian salt commodities are competitive or not. RCA value $>$ higher than 1 indicates that the product or commodity has a high comparative advantage in the market. Conversely, if the RCA value <less than 1 , this the commodity is less able to compete competitive in the global market because it is notdue to its low efficiencyt. Based on Table 2, ilt can be seen from Table 2 that compared with the other three countries, that at a glance Indonesia's has the lowest comparative advantage compared to the other three countries. advantages are clear at a glance.

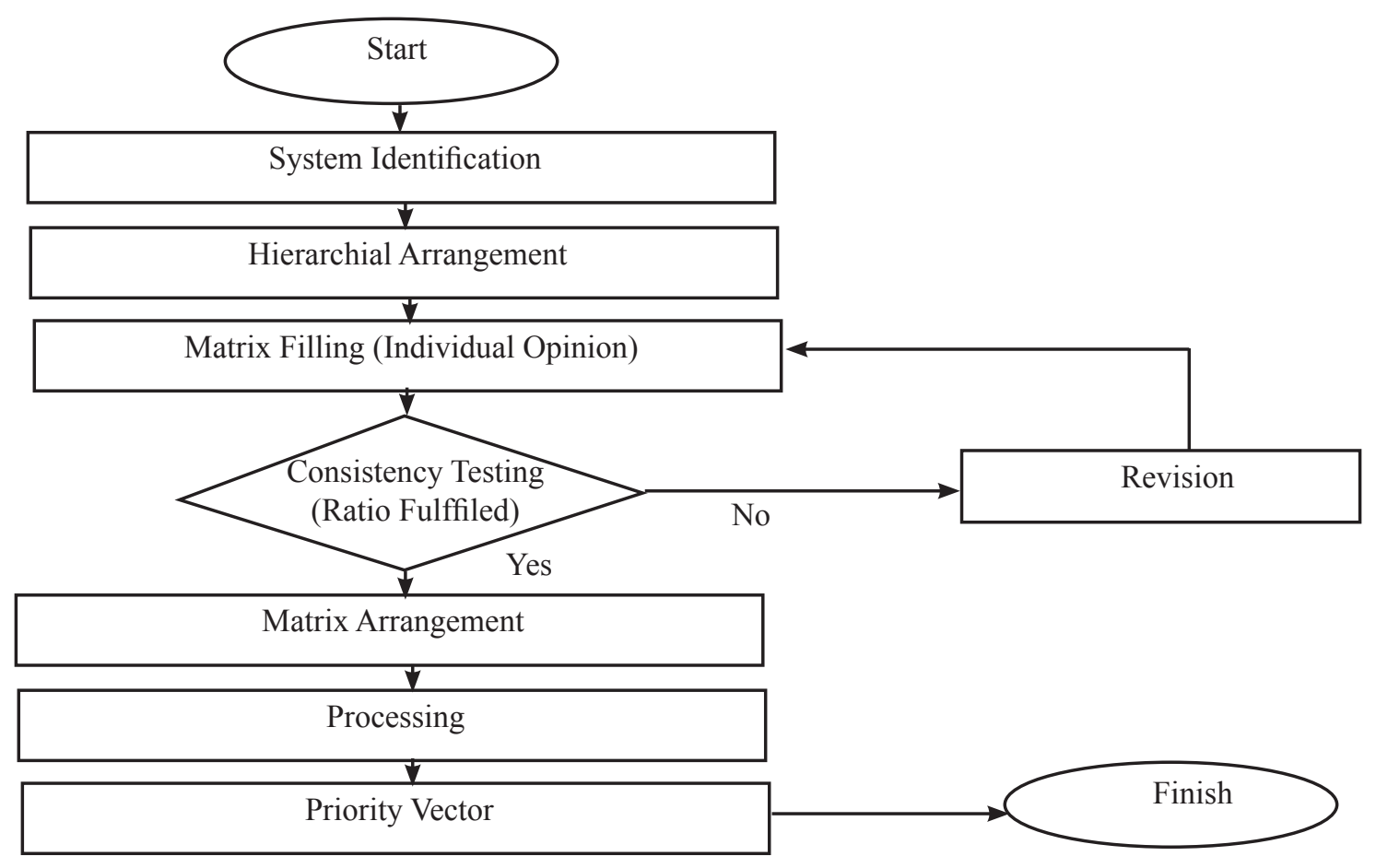

Figure 1. Schematic of data processing Analytic Hierarchy Process (AHP) (Satty, 1993) 
Because Since the range of value of the RCA index value range has an infinite range, it is improvements improved are made by making the RCA index symmetrical with a value interval between -1 to +1 which is known ascalled Revealed Symmetric Comparative Advantage (RSCA) (Prasad, 2004). A positive RSCA value indicates that the product or commodity has a high comparative advantage in the market. ConverselyOn contrary, if the RSCA value is negative, then this the commodity is less able to compete not competitive because it is inefficient and does not have a comparative advantage. Based on the RSCA value, it is also found that the competitiveness of salt commodities is still far much lower than that of below other countries such as Australia and the Netherlands. Meanwhile, the results of calculations related to RSCA can be seen shown in Table 3.

PT Garam, as a BUMN company engaged in with the oldest longest history in the Indonesian salt production in Indonesia industry, must formulate a strategy to increase the competitiveness of national salt, by involvingincluding internal experts from all directors, general managers, and senior managers, as well as external experts using the AHP methods. Based on the established AHP framework that has been created, PT Garam plans to carry out alignment actions at in the strategic house of PT Garam's strategic houses and the food clusters to adjust the direction of development inin the 2020-2024 development direction. BasedonFrom the synthesis of the results of expert justification judgment (30 experts), using the AHP method which is processed using super decisions, it can be seen that the alternative strategy to increase improve the competitiveness of national salt towards self-sufficiency and sustainability is formulated into five sub-strategic levelsy strata. Where in the on-farm strategy, the main alternative sub-strategy is the intensification sub-strategy (0.172), with intensification which can be done achieved by increasing in terms of salt production. Wati et al (2013) also suggested proposed that increasing the production of raw material salt and, as well as processed salt is a competitive strategy for the salt industry.

Table 2. RCA values for Indonesia. India. Australia and the Netherlands

\begin{tabular}{ccccc}
\hline \multirow{2}{*}{ Year } & \multicolumn{3}{c}{ RCA } & \\
\cline { 2 - 5 } & Indonesia & India & Australia & Netherland \\
\hline 2015 & 0.0136 & 2.1924 & 0.0791 & 2.7204 \\
2016 & 0.0106 & 2.2444 & 0.1022 & 2.4227 \\
2017 & 0.0006 & 2.8542 & 0.0673 & 2.4946 \\
2018 & 0.0028 & 3.2742 & 0.0657 & 2.5234 \\
2019 & 0.0042 & 3.3187 & 0.0878 & 2.2567 \\
\hline
\end{tabular}

Source : UN COMTRADE, 2020 (processed)

Table 3. RSCA values for Indonesia, India, Australia, and the Netherlands

\begin{tabular}{ccccc}
\hline \multirow{2}{*}{ Year } & \multicolumn{3}{c}{ RSCA } & \\
\cline { 2 - 5 } & Indonesia & India & Australia & Netherland \\
\hline 2015 & -0.9731 & 0.3735 & -0.8534 & 0.4624 \\
2016 & -0.9789 & 0.3835 & -0.8145 & 0.4157 \\
2017 & -0.9883 & 0.4811 & -0.8738 & 0.4277 \\
2018 & -0.9943 & 0.5321 & -0.8766 & 0.4324 \\
2019 & -0.9916 & 0.5369 & -0.8385 & 0.3859 \\
\hline
\end{tabular}

Source : UN COMTRADE, 2020 (processed) 
The main intensification activity activities can be done carried out through land integration, by salt farmers through land consolidation. Through land the integration of land, farmers can produce better quality, besides that the better quantity is also better and low production costs are also decreasing. The salt integration process includes the entire series of salt formation processes starting from the evaporation area, crystallization to being its processed processing into salt. The existence of land integration can also make the salty land closer to the road, as well so that the transportation costs can also be lower. In order to To support an integrated salt area, there is a need for cooperation between parties such as Geospatial Information Agency (in Indonesian BIG), Ministry of Marine Affairs and Fisheries (KKP), National Land Agency (BPN), local government (Pemda), and PT Garam itself. Other activities that PT Garam can be carried out by PT Garam in the intensification strategy are providing provision of agricultural technology and building infrastructure aimed at optimizing/utilizing assets. The main problem of salt producer in making technology and agricultural infrastructure for salt farmers is regarding the harvesting mechanism. Salt farmers do not have a good harvesting mechanism, so that they salt purification is do not purify the salt. This makes carried out which causes farmers' the salt to not be of high quality of the producer low, and the salt is removed during the salt drying process. The location of the crystallization table that platform is far apart in the salt drying process makes it farmers have difficulty for farmers to increasingincrease their production, which has been the consumption of table salt into in industrial salt. Through with the cooperation of enterprises and between companies and institutions, it is hoped that salt farmers can have a good harvesting mechanism and adequate sufficient infrastructure so that salt farmers can to enable them to produce quality salt.

Meanwhile, the regulation/policy of salt intensification has been explained in the Peraturan Ministerial Regulation of Menteri Industry Republic of Perindustrian Republik Indonesia Nomor Number 88/M-IND/PER/10/2014 concerning amendments Peraturan Menteri PerindustrianMinisterial Regulation of Industry nomornumber 134/M-IND/PER/10/2009 concerning the guide map (road map) of salt industry cluster development. The policy targets are divided into medium-term and long-term in which therewith the are policies policy related to the intensification of salt land, increasing and the productivity of salt fields and salt products. Yonvitner and Akmal (2019) in their research stated that the revitalization of potential and productive ponds in the form of mapping productive and potential land mapping is one of the a national salt pond business interventions to realize self-reliance. The Mmapping productive land is also one a way to increase salt production intensively.

The second alternative sub-strategy is extensification (0.069), which where one of the activities that can be carried out is to increaseing salt so that one of the activities that land which can be done performed to increase the production of salt production. Alternative extensification can be done by establishing a new factory for the to production produce of both consumption salts consumedand production salt. The policy related to extensification has also been explained in the Peraturan Menteri Perindustrian Republik Indonesia Nomor Ministerial Regulation of Industry Republic of Indonesia Number 88/M-IND/PER/10/2014. Where one of this policy targets objective is the extensification of salt production land in the Madura-Sampang area. The extensification activity carried out by PT Garam to reduce production costs of PT Garam is to expand the land by fulfilling the fishing grounds. In the this process, PT Garam was unable to enter into could not participate in the partnerships with farmers due to Law Number 7/ of 2016 concerning the Protection and Empowerment of Fishermen, Fish Cultivators and Salt Farmers, which guarantees salt farmers to have rights to their salt land. Therefore, PT Garam intends to will acquire salt fields in Australian salt fields, this results in greaterwhich will increase profits and also, reduces the costs of production, costs and also reduces transportation costs.

The last alternative sub-strategy in the on-farm strategy is, namely, Utilization utilization (0.028). The notion of utilization can be interpreted as exploitation to bring results and benefits and outperform tasks. The form of utilization in the salt industry can be done through partnerships. PT Garam must cooperate with salt farmers considering that the majority of the salt production in Indonesia is produced by smallholder farmers (KKP, 2015). Policies related to the utilization of smallholder salt farmers can be seen in the Decree of the Director General of Marine Spatial Management Keputusan Direktur Jenderal Pengelolaan Ruang Laut Nomor Number 1/KEP-DJPRL/2020 concerning Technical Guidelines for the Development of People's Salt Businesses in 2020 where one approach to focusing 
on the development of the developing people's salt businesses is through corporatization, namely business institutions. Irawati (2014) in her research saidstated that the form of the way to empower people's salt business empowerment is one of the strategies for developing salt commodities through a partnership approach. Meanwhile, according to Setyaningrum et al. (2015) stated that the measurement of the level of empowerment was carried outis measured through several very important aspects to show demonstrate the level of empowerment of salt business craftsmen for empowerment including production aspects, distribution aspects, market demand aspects, and cultural aspects.

In the Marketing strategy, the main alternative substrategy is processed refined salt $(0.076)$. where theThe strategy to increase the marketing ofrefined processed salt marketing is to carry out conduct intensive distribution of refined for processed salt and establish cooperation with BUMN or private companies to increase marketing to the retail level (Wati, 2015). The strategy related to salt marketing is also related to policiesthe commercialization of salt is also related to the Regulation of the Minister of Trade of the Republic of Indonesia Number 63 of 2019 concerning Provisions for on the Importing of Salt. While the last alternative sub-strategy in the marketing strategy is raw salt (0.015).

In the Off-Farm strategy, the main alternative substrategy is Downstreaming downstream (0.414) which can be done achieve by increasing through the addition of processed salt production every year. The notion concept of downstream can also be interpreted as the result process of changing the results of raw materials in the upstream industry, and which then produces processed products or finished products in the downstream industry. According to the Ministry of Industry (2016), downstream can be done to increase added value and strengthen the structure of the industry itself. In addition, it strengthens the role of the industrial sector in the economy and improves people's welfareincome of the people. The Aactivities that can be carried out related to the downstream strategy are to integrate business development into salt production through the construction of off-fam corporate and downstream processing plant construction. In addition, a connected supply chain is also carried out where there is transparency has been established in which in the prices of all commodities in agriculture to the final consumer are transparent.

The second alternative sub-strategy is industrial salt (0.178) and its derivatives, which are related to making development of target market strategies based on consumer segmentations. The development of industrial salt is also expected to produce high quality, according to industry standards, competitive prices, and produce high margins that meet industry standarda. In addition, production needs to be increased it is necessary to increase the amount of production to meet the need demand for industrial salt. According to Mustofa (2016), since the industrial salt market is still very open, the application strategy of to geoisolator technology can be used to produce high-quality salt because the industrial salt market is still wide open. Regarding industrial salt the import policy, for industrial salt, it has also been explained in the Ministerial Regulation of Trade, Republikc of Indonesia Number Number 52/MDAG/PER/8/2017 concerning the Second Amendment to the Ministerial Regulation of Trade Number 125/MDAG/12/2015 concerning Provisions on Salt Imports.

Meanwhile, according to the Ministerial Regulation of Industry, Republic of Indonesia Number 88/M-IND/ PER/10/2014 concerningAmendments to the Ministerial Regulation of Industry, Republic of Indonesia Number 134/M-IND/PER/10/2009 concerning the Road Map for the Development of the Salt Industry Cluster, where there is a change in the salt cluster for various foods into the need for industrial salt, which previously included the salt cluster for various foods into the consumption salt cluster. By definition, various foods are included in the category of community needs, which should be included in the consumption salt cluster. Since the standard is not meet, this will lead to This causes the absorption of people's absorbing sub-optimal salt production to be less than optimal due to unmet standards.

While Although the last alternative sub-strategy on the off-farm strategy is Ssalt for Cconsumption (0.045), where the market segmentation is mostly for themainly directed to the end consumers. Indonesian National Standard (SNI) 3556-2010 regarding iodized salt consumption, the minimum required $\mathrm{KIO} 3$ level is a minimum of $30 \mathrm{mg} / \mathrm{kg}$ based on Atas Dasar Bahan Kering (ADBK). However, some of the competencies of domestic salt processing SMEs have not been able fail to meet the SNI, which makes making it difficult to compete in the market competition difficult. 
Referring to Herman et al. (2014), salt consumption is a commodity a good thing, and that is continuously needed by the whole community needs to constantly make, to give food a salty taste. Because its irreplaceable function cannot be replaced, consumption salt is included in a strategic commodity group, and its whose trade trading system is regulated to maintain a stable supply in the community. Several key factors tend to trigger often the salt crisis, including the sale prices of salt, weather, salt companies, trade regulations, and innovation factors drivers. According to Amien \& Adrienne (2020), the need demand for salt consumption salt has been met satisfied by national production. However, industrial demand is need, and it is still partially fulfilled met by domestic production and imports. Until now, there is no single national data system related to the quantity amount of production, consumption, and imports (industrial salt). The data relating to salt is spread from agencies of the Ministry of Trade, Ministry of Industry, Ministry of Maritime Marine Affairs and Fisheries, PT Garam (Persero), and business associations. In 20152018, The import volume of imported salt imports experienced showed and an increasing upward trend from 2015 to 2018, but there was a decline decreased in 2019.

The factors that can influence affect the salt competitiveness strategy of the Indonesian salt industy in Indonesia are Regulation regulation (0.345), infrastructure $(0.291)$, quality $(0.162)$, price $(0.089)$, technology (0.055), human resources capability (0.035), and capital (0.019) (Figure 1). The influential participant's priority priorities of the influential actors are the Government (0.406), PT GARAM (0.267), the end-user $(0.176)$, the processor $(0.086)$, Farmers/Ccooperatives (0.040), and Funding financial Institutions (0.022). This means that supporting the strategy to increase improve the competitiveness of the salt industry, requires full the commitment and full support from of the government, especially regulations/policies related to increasing improving the national salt industry power industry towards selfsufficiency and sustainable development of the national salt industryility. Existing regulations should support, facilitate promote and create a conducive climatean enabling environemnt. If the regulation is good and supports and facilitates promotes the development increasing the power of the national salt industry, it needs to be supported bythe support of policy makers and stakeholders is needed, especially political will and high commitment from of the ministerial level policy makers, as well as stakeholders, especially at the ministry level. In addition, synergies coordination and synchronization between institutions are is needed so that all have everyone has a one vision and goal, to increase improve the competitiveness and selfsufficiency of the national salt industry in a sustainable manner.

Regulations that can To support being more the improvement of the salt competitiveness, it is necessary for the Coordinating Minister for Maritime Affairs and Investment of the Republic of Indonesia to make decision under the authority of salt as a national strategic commodity is to make salt an important commodity. Where the change can be made by drafting the Coordinating Minister for Maritime Affairs and Investment of the Republic of Indonesia to include salt as a basic and important item by following the mandate of Peraturan Presiden Presidential Decree number 59/2020 to include salt as a basic needs and important goods. concerning the Determination and Storage of Staples of Basic Needs and Important Goods The revision of the determination of salt commodity identification review as a staple product will encourage the government to set a establish a reference price for salt. Determination of this the reference price will reduce the risk received of by salt farmers due to fluctuations in the salt prices of salt.

Before using imported products, The marketing strategy strategies appears seem to love prefer theto use of domestic production before using imported products. The market is a determinant determining factor in of the competitiveness of a commoditycommodities. Unfortunately, up to now, so far there has been a the practice of market clustersing approach that makes the has resulted in a surplus of national domestic supply of salt experience an excess every each year, this causes the number of causing imports to exceed industrial needsdemand. In addition, Moreover, there are problems with SNI problems which have been causing created technical barriers to local products and, whereas technical barriers should have been created must be established to support local products and hinder imported products.

The government has been using always used the concept of MBV concept in when implementing existing policies, this concept has which believes the view that 
if a commodity can have a be produced efficiently at a lower cost, the product can have a competitive advantage if it has a low cost in producing commodities efficiently. This results in has caused a large number quantities of imported products to entering the market, and making local products lose their appealun attractive. In the long term, this will have an impact on the welfare income of the Indonesian people farmers. The government needs to change the concept that was should transform the previously MBV concept into a RBV, which is a concept that pays more attention focused on to the uniqueness and production. The capabilities based on local resources so that makes local products can have value in being competitive.

Broadly speaking, the on-farm strategy is an effort to improve and increase the effectiveness of agriculture on the land, such as land intensification, land extensification, utilization and includes productivity. In addition, there is also an off-farm strategy, which is activities to includes increase increasing the use of national salt production based on the principle of uniqueness and potential around existing resources which are divided into the categories of industrial salt, consumption salt, and downstream categories based on the principles of uniqueness and potential. The Mmarketing strategy is a strategy that prioritizes local products rather than the imports of that prioritizes raw material salt and processed salt.

\section{Managerial Implications}

The managerial implications of this research have an impact on implications for the main stakeholders of national salt, the government and PT Garam. The government must should immediately evaluate the regulations of governing the salt trade trading system, remove eliminate overlapping authorities and encourage the creation establishment of salt-based industries around salt production centers., in addition Furthermore, that a revision is needed regarding the determination of salt clustering so that there are to changes to the salt import map that makes salt imports consumption is are subject to import duty.

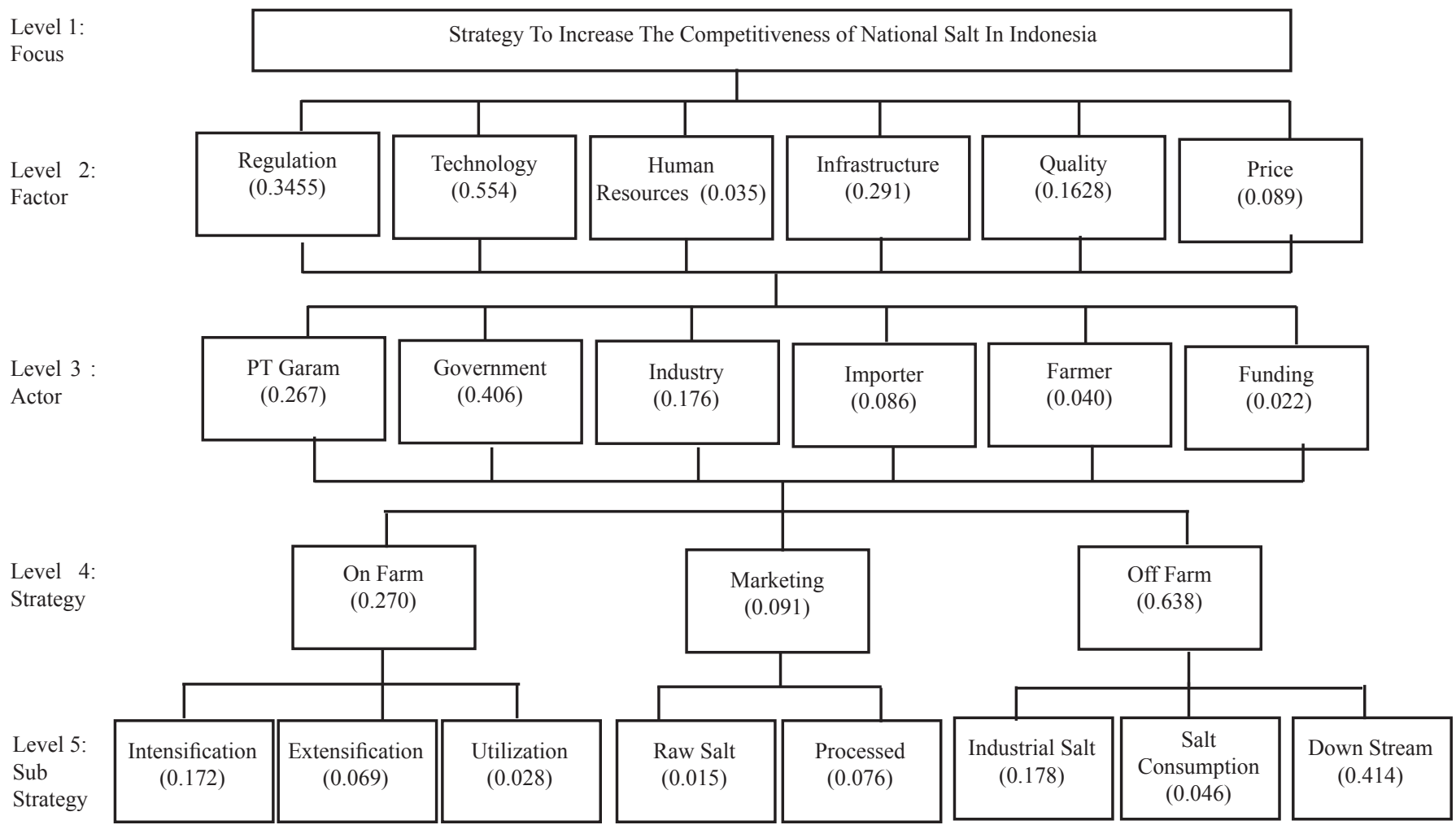

Figure 2. The Hierarchical AHP processing results 
PT Garam must consistently implement off-farm strategiesstrategy, on-farm strategiesstrategy, and marketing strategies. External pressure in the form of low salt prices has become a driving force momentum for self-improvement, business, and management transformation. Businesses must be shifted moved from focusing an on-farm focusing to an off-farm focus. Priority must be given to improving the quality of onfarm products, must be prioritized as well while rapidly increasing the quantity quickly to enhance corporate performance, with and the immediate acquisition acquiring of Australian salt fields in Australia.

\section{CONCLUSIONS AND RECOMMENDATIONS}

\section{Conclusions}

Based on the results of the RCA analysis using RCA, the RCA value for of Indonesian salt commodities in Indonesia is still $<1$. Therefore, so it is concluded that salt commodities are less able to compete competitive in the global market because they are not efficient. To avoid the occurrence of asymmetryical in the calculation problems of the value of the RCA index value, an analysis of calculations analysis usingwas performed using the RSCA was carried out. Among them, where the RSCA value for of Indonesia was is negative. so that ilt could can be said that the salt commoditiesy was less lack competitiveness because it was inefficient and did not have a no comparative advantage due to low efficiency. When compared to other countries, this commodity of national salt product has a lower comparative advantages and is less able to lower compete competitiveness because it is considered inefficient. Therefore, it is necessary to analyze the strategy strategies that must be carried out implemented so that the salt production of salt is reaches self-sufficientcy and can be competitive.

The Resources Based View (RBV) approach will make national salt production sustainable and competitive to in order to improve the welfare income of the community. In addition Furthermore, the strategies and corrective measures actions taken to allow the so that policies policy to play its best role through can work optimally through on-farm, off-farm strategies, as well as and long-term marketing strategies in the long term will ensure that the fulfillment of the supply of local salt needs in terms of quantity and quality of the local demad for salt, as well as the certainty of local salt in the market, they are fulfilled and people will choose to use products made from with local raw materials.

\section{Recommendations}

The salt commodity as an "Important Goods Commodity" must be re-established so that the government returns to be present can reappear to regulate the national entire country's salt trade system as a whole. In addition, a policy from the government policies isare needed to ensure the that import quota policy policies is only shown to cover the meet needs of the industry needs. The government also needs should also to change the concept of the MBV which has been used so far to become a RBV to show partiality to the preference for local product production of local commodities. The clustering concentration of consumption consumer salt and the industry should also needs to be thoroughly reformed reviewed to provide opportunities for local producers to compete fairly in the market fairly. food industry salt cluster.

\section{REFERENCES}

Amien DD, Adrienne F. 2020. Tantangan dan potensi garam nasional. https://ppi.id/. [24 Nov 2020].

Ardiyanti ST. 2016. BAB II Produksi Garam Indonesia. Jakarta: Badan Pengkajian dan Pengembangan Perdagangan.

Baihaki L. 2013. Ekonomi-politik kebijakan impor garam Indonesia pPeriode 2007-2012. Jurnal Ilmu Sosial Dan Ilmu Politik 17(1):1-16.

Banumathi RR, NadarajanS. 2015. Marketing strategies and practices with reference to salt industries in Tamil Nadu India. International Journal of Management 6(3): 34-37.

Biro Komunikasi Kementerian Koordinator Bidang Kemaritiman dan Investasi. 2018. Menko maritim luncurkan data rujukan wilayah kelautan Indonesia. https://maritim.go.id. [28 Feb 2021].

BPS. 2020. Impor garam menurut negara asal utama, 2010-2019. Badan Pusat Statistik. https://www. bps.go.id/statictable/2019/02/14/2013/imporgaram-menurut-negara-asal-utama-2010-2019. html. [1 Mar 2021].

Dharmayanti S, Suharno, Rifin A. 2013. Analisis ketersediaan garam menuju pencapaian swasembada garam nasional yang berkelanjutan (suatu pendekatan model dinamik). Jurnal Sosial Ekonomi Kelautan Dan Perikanan 8(1):103- 
115. https://doi.org/10.15578/jsekp.v8i1.1201.

Garampedia. 2020. Kenapa Iindonesia masih garam impor. https:// garampedia.com. [28 Aug 2020].

Herman SS, Eriyatno, Noor EE, Mulyadi D. 2014. Identifikasi faktor kunci krisis pada tataniaga garam konsumsi di Iindonesia menggunakan proses jejaring analitik (analytic network process). Jurnal Riset Industri (Journal of Industrial Research) 8(3): 205-214.

Irawati S. 2014. Strategi pengembangan komoditi garam di Kabupaten Sampang melalui pendekatan kemitraan. 3rd Economics \& Business Research Festival : 222-231

Kementerian Perindustrian. 2016. Media industri industrialisasi menuju kehidupan yang lebih baik. https://www.kemenperin.go.id. [11 Mar 2021].

[KKP] Kementerian Kelautan dan Perikanan. 2015. Laporan kinerja kementerian kelautan dan perikanan tahun 2015. https://kkp.go.id. [11 Mar 2021].

Liu Y, Han T, X Wei. 2016. Beijing Salt Company: The way to deal with the salt reform program. American Journal of Industrial and Business Management 6: 1185-1193. https://doi. org/10.4236/ajibm.2016.612109.

Muenshriphu C, Vichvavichien S, Jinarach S. 2010. Strategic exploration of salt international company in Thailand: Can they have sustainable growth and profits?. Journal of Business Studies Quaterly 1(3): 68-81.

Mustofa A. 2016. Strategi pengembangan usaha garam rakyat di Kecamatan Kedung Kabupaten Jepara.
Jurnal DISPROTEK 7(2): 22-29.

Prasad R. 2004. Fiji's Export Competitiveness A Comparison with Selected Small Island Developing States. Fiji: Reserve Bank of Fiji.

PT Garam. 2020. Laporan PT Garam. https://www. ptgaram.com. [29 Aug 2020].

PT GaramARAM. 2017. Pengembangan area industri PT. Garam (persero) di Teluk Kupang - Nusa Tenggara Timur. https://www.ptgaram.com. [29 Aug 2020].

Pusidrosal. 2018. Data kelautan yang menjadi rujukan nasional diluncurkan. http://pushidrosal.id. [1 Mar 2021].

Salim Z, Munadi E. 2016. Info komoditi garam. http:// bppp.kemendag.go.id. [28 Aug 2020].

Setyaningrum A, Udaya J, Efendi. 2015. PrinsipPrinsip Pemasaran. Ed. ke-1. Yogyakarta: Andi. (Edisi 1).

Suhendi, Abdullah AA, Shalihati F. 2020. The effectiveness of the salt policy in Indonesia. Jurnal Manajemen\& Agribisnis 17(3): 315. https://doi.org/http://dx.doi.org/10.17358/ jma.17.3.315

Wati, Daryanto, Setiawan. 2015. Pengembangan stategis bersaing PT. Garam (Persero) dalam tataniaga garam Indonesia. Jurnal Kesejahteraan Sosial 2(1): 21-26. https://doi.org/10.31326/jks. v2i01.149.

Yonvitner, Akmal SG. 2019. Membangun tata kelola garam berdaya saing. Risalah Kebijakan Pertanian Dan Lingkungan 6 (1): 53-59. https:// doi.org/10.29244/jkebijakan.v6i1.28765. 